\title{
INTERPRETASI TEORI DELEUZE DAN GUATTARI DALAM ARSITEKTUR
}

\author{
Solaiman Bakir, Melania L. Pandiangan, Genie Anggita, Rangga Alexander \\ Magister Arsitektur, Sekolah Arsitektur, Perencanaan dan Pengembangan Kebijakan, \\ Institut Teknologi Bandung \\ Labtek IXB ITB, Jl.Ganeca No.10 Bandung, Jawa Barat, Indonesia \\ bakireman@yahoo.com
}

\begin{abstract}
Abstrak
Filsafat mempengaruhi arsitek melalui teori-teori sebagai dasar ide dalam melakukan perancangan. Hal ini dapat dilihat pada perkembangan arsitektur kontemporer yang mencoba menerapkan filsafat dekonstruksi dalam langgam arsitektur dekonstruktivisme, atau dapat diamati pula dalam literatur arsitektur yang mencoba mengangkat tema filasafat fenomenologi dan sebagainya. Contoh ini mengungkapkan bahwa adanya hubungan antara garis pemikiran filsafat dengan ilmu rancang bangun. Dalam konteks inilah maka ide atau filsafat itu menjadi penting atau bahkan merupakan sebuah alternatif dalam mengeksplorasi dan menggali gagasan-gagasan baru di dunia penciptaan Arsitektur. Gilles Deleuze dan Felix Guattari adalah dua orang pemikir/filsuf yang revolusioner. Pemikiran mereka juga mempengaruhi arsitektur meskipun belum banyak yang mencoba menerapkan teori mereka secara langsung ke dalam desain perancangan arsitektur. Dalam tulisan ini kami mencoba menginterpretasikan teori-teori Deleuze dan Guattari tentang konsep DesireMachine, Territorialization-Deterritorializatiion-Reterritorialization, dan Rhizome and Tree serta alternatif penerapannya dalam bidang arsitektur yang berupa citra dan gagasan perancangan.
\end{abstract}

Kata kunci: Deleuze dan Guattari, desire-machine, territorialization-deterritorializatiionreterritorialization, rhizome and tree.

\begin{abstract}
Title: Interpretation of Deleuze and Guattari Theories in Architecture

Philosophy influenced all architects through theories of philosophy which is it acted as a set of the idea to practice in design. It is can be looked at the contemporary architectural trend which trying to demonstrated the deconstruction philosophy through architecture style, or it is can be observed in architecture literature which trying to adopt the philosophy of phenomenology and so forth. These examples revealed that there are relationship between philosophy and architecture. So, In this case, the philosophy become very important and then to be an alternative in term of exploration and searching the new concepts of creation of architecture. Both of Gilles Deleuze and Felix Guatari are thinkers or philosophers that revolutionary. Their thought influenced architecture although not so much whom that directly apply their work. In this paper, we try to interprete their toughts which covered Desire-Machine Concept, TerritorializationDeterritorializatiion-Reterritorialization Concept, and Rhizome-Tree Concept as well as its application in the field of architecture. It can be an image or an idea of design.
\end{abstract}

Keywords: Deleuze and Guattari, desire-machine, territorialization-deterritorializatiionreterritorialization, rhizome and tree. 


\section{Pendahuluan}

Arsitektur dan Filsafat merupakan dua bidang ilmu yang terpisah. Namun dengan melihat kembali konteks sejarah terbentuknya ilmu pengetahuan, maka dapat diamati bahwa induk segala ilmu adalah filsafat itu sendiri. Dengan demikian maka mudah dipahami bahwa secara tidak langsung terdapat hubungan antara arsitektur dan filsafat. Hubungan ini dipertegas lagi oleh para filsuf dengan mengkaji arsitektur dari sudut pandang filsafat, seperti yang dilakukan oleh Heidegger (1991 dalam esainya yang berjudul Building, Dwelling, Thinking. Esai ini pula yang pada perkembangan selanjutnya menginspirasi Schulz (1988) dalam menyusun bukunya yang berjudul Meaning and Place, seperti yang dikatakan Nesbit (1996:412) berikut ini, "From his early writings in the 1960s to the more recent Architecture: Meaning and Place (1988), he develops a textual and pictorial interpretation of the ideas of Martin Heidegger's essay: Building Dwelling Thinking". Esai mengenai arsitektur yang di telaah oleh para filsuf dapat dilihat juga pada kumpulan bunga rampai (anthology) yang disusun oleh Mallgrave dan Contandriopoulos (2008). Dalam kumpulan esai itu bisa diamati bagaimana para filsuf seperti Friedrich Nietzsche, Jürgen Habermas, Jean François Lyotard serta Gilles Delleuze memandang Arsitektur dari sudut pandang masing-masing.

Dari esai-esai di atas bisa diamati adanya hubungan antara garis pemikiran filsafat dengan ilmu rancang bangun. Meskipun hubungan ini tidak tampak sejelas kita melihat bangunan secara fisik. Artinya bahwa pengaruh filsafat dalam arsitektur tidak akan tampak jelas pada aspek permukaan fisik bangunan namun akan menjadi jelas apabila kita dapat menyelami gagasan-gagasan besar dibalik apa yang tampak secara fisik. Dalam konteks inilah maka ide atau filsafat itu menjadi penting atau bahkan merupakan sebuah alternatif dalam mengeksplorasi dan menggali gagasangagasan baru di dunia arsitektur. Hal ini senada dengan apa yang dikatakan Adam Shaarr dalam Ballantyne (2007) bahwa, "Architects have often looked to thinkers in philosophy and theory for design ideas, or in search of a critical framework for practice".

Deleuze dan Guattari adalah dua orang pemikir yang revolusioner. Pengaruh mereka tidak dapat dipandang sebelah mata dalam kancah pemikiran Eropa di Abad 20. Pemikiran mereka juga mempengaruhi arsitektur meskipun belum banyak yang mencoba menerapkan teori mereka secara langsung ke dalam desain perancangan arsitektur. Sampai saat ini hanya terdapat telaah yang mencoba membahas teori Deleuze dan Guattari dalam ranah arsitektur, seperti yang ditulis oleh Ballantyne (2007) dalam buku Thinkers For Architects : Deleuze \& Guattari For Architects.

Tulisan ini bermaksud menginterpretasikan buku tersebut yang terdiri atas teori-teori Deleuze dan Guattari seperti konsep Desire-Machine, Territorialization-DeterritorializatiionReterritorialization, dan Tree and Rhizome, serta alternatif penerapannya dalam bidang arsitektur yang berupa citra dan gagasan perancangan. Adapun metode penelitian dalam kajian ini menggunakan kajian pustaka dalam pengumpulan data dan menguraikan hasilnya secara deskriptif. Tujuan penulisan ini adalah untuk menambah wawasan tentang arsitektur dari perspektif filsafat serta memberi 
kemungkinan untuk bisa dipraktekkan dalam karsa dan karya, baik sebagai calon arsitek maupun Arsitek.

\section{Studi Pustaka}

Sebelum memahami filsafat Deleuze dan Guattari, alangkah baiknya perlu diketahui juga sosok Gilles Deleuze dan Felix Guattari beserta karya-karya mereka, baik yang dihasilkan oleh Deleuze sendiri, atau Guattari, serta karya monumental yang merupakan kolaborasi keduanya. Selain itu, perlu dipertimbangkan juga konteks sejarah perkembangan filsafat saat itu beserta konteks sosial, ekonomi, politik dan perkembangan intelektual Perancis di Abad 20, di mana Deleuze dan Guattari hidup. Hal ini dianggap penting sebagai upaya dalam memahami konsep atau ide dari pemikiran Deleuze dan Guattari secara makro meskipun belum terlalu mendalam.

\section{Biografi Gilles Deleuze}

Gilles Deleuze lahir di Paris pada Tahun 1925, dalam lingkungan keluarga yang konservatif. Ia sekolah di Lycěe Carnot, Paris dan kemudian menjadi mahasiswa filsafat di Sorbone pada pertengahan 1940. Pada masa kuliahnya Ia banyak mendalami tradisi filsafat rasionalis sebagai bentuk penghargaan terhadap sejarah filsafat yang merupakan fondasi bagi disiplin rasionalisme. Setelah menyelesaikan studinya pada tahun 1949, Ia mulai membangun pengetahuannya tentang filsafat dengan mempelajari sejarah filsafat, namun dengan minat yang berbeda sewaktu Ia menjadi mahasiswa. Dimulai dengan mempelajari filsafat Eksistensialisme, Fenomenologi, Filsafat Hegel dan sebagainya. Yang menarik pada massa 'pengeraman' idenya ini adalah ia dengan tekun dan teliti mempelajari para pemikir yang mempunyai kecenderungan 'dualisme', di mana di satu sisi kelihatan membangun suatu rangkaian dengan sejarah filsafat, namun di sisi yang lain berupaya untuk meninggalkannya. Pemikir-pemikir ini digolongkan oleh Deleuze sebagai pemikir yang anti rasionalis, seperti Lucretius, Spinoza, Hume, Bergson, dan Nietzsche. Sebagai hasil kajiannya terhadap para pemikir ini dan juga mungkin bentuk penghormatannya, Ia mempublikasikan karya-karya yang membahas tentang Hume pada Tahun 1953, esai tentang Lucretius pada Tahun 1961, sebuah buku tentang Bergson Tahun 1966, tentang Spinoza pada Tahun 1966 dan Nietzsche pada Tahun 1962, yang merupakan tokoh sangat berpengaruh dalam perkembangan pemikiran Deleuze (Hartono, 2007 : 59). Gilles Deleuze meninggal pada tanggal 5 November 1995 dengan cara yang tragis, yakni melemparkan diri dari apartement kediamannya. Karya yang dihasilkannya selain yang disebutkan di atas yang berupa esai dan buku adalah sebagai berikut : Instinct et Institutions (1953), Kant's Critical Philosophy: The Doctrine of The Faculties (1963), Proust and Sign (1964), The Logic of Sense (1969), Dialogues (1977), Cinema I : The Movement Image (1983), Cinema II : The Time Image (1985), Critique et Clinique (1993) dan masih banyak lagi.

\section{Biografi Felix Guattari}

Felix Guattari lahir pada Tahun 1930 dalam keluarga kelas menengah di pinggir barat laut Paris. Sejak masa muda Dia sudah aktif dalam pergerakan politik. Tamat dari pendidikan menengah Ia melanjutkan pendidikan tingginya dengan menjadi seorang mahasiswa jurusan Filsafat dan Farmasi sekaligus. Dengan bekal 
pendidikan ini dan pergulatannya di bidang politik, maka ia menjalani tiga profesi, yaitu sebagai aktivis politik, psikiatris dan pemikir. Guattari meninggal pada Tahun 1992. Karyakarya yang dihasilkannya adalah sebagai berikut: La Révolution Moléculaire (1977), L'Inconscient Machinique (1979), Psychiatry and Politics (1984), Les Espaces de Liberté (1985), Les Anné d'Hiver (1986) dan Cartographies (1989).

\section{Karya Kolaboratif Deleuze-Guattari}

Karya kolaborasi mereka dimulai pada tahun 1972 dengan menerbitkan buku berjudul Anti-Oedipus : Capitalism and Schizophrenia I, kemudian disusul dengan Kafka: Toward a Minor Literature (1975), Rhizome (1976), A Thousand Plateaus : Capitalism and Schizophrenia II (1980), dan What is Philosophy (1991). Di antara karyakarya ini, yang paling monumental dan menjadi Masterpiece adalah AntiOedipus (Hartono, 2007: 67). Dalam buku ini mereka mengkritik pemikiranpemikiran yang terlalu menonjolkan rasionalitas dan cenderung mengabaikan aspek lain yang dalam istilah Deleuze dan Guattari disebut sebagai hasrat. Pemikiran-pemikiran ini adalah paham Modernisme, Psikoanalisis Freud, Psikoanalisis Lingustik Lacan dan Marxisme Tradisional.

Deleuze dan Guattari membangun teorinya berdasarkan pada kritik mereka terhadap pemikiran di atas yang cenderung hirarki dan tersentralisasi, namun tetap dalam kerangka pemikiran filsafat Nietzsche. Jadi sampai di sini kita melihat bahwa begitu besar pengaruh Nietzsche bagi mereka berdua yang menganggap aspek hasrat manusia adalah sama penting dengan aspek rasio. Nietzsche dalam hal ini mendeklarasikan kematian Logos atau rasio lalu kemudian menggantikannya dengan hasrat manusia. Deleuze dan Guattari menggunakan konsep ini untuk merayakan seluruh energi murni dalam aktivitas yang bebas, dalam konsep Nietzsche diistilahkan sebagai 'kehendak untuk berkuasa' (Hartono, 2007 : 70).

\section{Perkembangan Filsafat Perancis pada Abad Ke 20}

Filsafat di Perancis pada Abad ke 20 masih mewarisi paham Descartian yang menitikberatkan rasio pada kedudukan superior. Sedangkan hasrat diletakkan sebagai the orphan desire atau 'anak yang hilang'. Rasio kemudian menjadi penentu mutlak dalam cara bereksistensi manusia. Sebaliknya hasrat hanya sekedar ada sebagai bagian dari pelengkap diri dan bukan penentu dalam proses berpikir dan bertindak. Sekalipun pada perkembangan selanjutnya terjadi revolusioner dalam mempelajari hasrat, terutama yang dilakukan oleh Freud lewat pengkajian psikoanalisisnya, namun tetap saja ada upaya-upaya memposisikan hasrat pada wilayah inferior. Begitu juga yang terjadi dengan Lacan dalam mengeksplorasi psikoanalisisnya. Oleh karena itu baik Filsafat maupun Psikoanalisis samasama mengembangkan hasrat tetap pada kerangka rasionalisasi. Hasrat telah direduksi menjadi unsur negatif, agar kekekalan rasio tetap lestari. Dalam kondisi demikianlah Deleuze dan Guattari tampil sebagai pembela hasrat untuk mendapatkan peran dan posisi yang sejajar dengan rasio. Karena menurut mereka hasrat memiliki peran penting dalam memainkan kreativitas subjek untuk lebih produktif, tentunya dengan konteks yang luas. 
Kondisi Sosial, Ekonomi dan Politik Perancis pada Abad 20

John Ardagh dalam Hartono (2007: 44) melukiskan keadaan Perancis pasca perang dunia II, yakni Perancis yang mengalami proses modernisasi secara spektakuler. Dalam bidang ekonomi pertumbuhannya meningkat dengan pesat, yaitu antara Tahun 1950 sampai 1970, sehingga Perancis dapat dikatakan sebagai Negara yang mengalami pertumbuhan ekonomi paling dinamis dan sukses di Dunia kala itu. Pertumbuhan ekonomi ini mengubah gaya hidup masyarakat Perancis dari masyarakat yang berbasis pertanian menjadi masyarakat yang berbasis urban sekaligus industrial. Perubahan ini membentuk realitas sosial baru berupa masyarakat dengan gaya hidup konsumerisme material dan citra, teknologi, industrialisasi, sekularisasi, diferensiasi sosial, komodifikasi dan rasionalisasi. Singkatnya masyarakat Perancis setelah perang dunia II berubah menjadi masyarakat post industrial.

Demikian juga dengan perkembangan politik yang terjadi kala itu, dipandang sebagai alat untuk melestarikan praktek kapitalisme yang hanya akan menguntungkan sebagian golongan, dalam hal ini para borjuis atau pemilik modal. Keadaan inilah yang memicu lahirnya teori-teori baru yang mencoba menyesuaikan berbagai cabang ilmu (sosial, teknologi, ilmu eksakta dan filsafat) ke dalam dinamika perkembangan kehidupan masyarakat Perancis.

\section{Kondisi Intelektual Perancis Abad 20}

Seperti yang telah disebutkan di atas bahwa kondisi intelektual Perancis juga dengan sendirinya mencari teori-teori yang dirasakan cocok dengan perkembangan zaman. Salah satunya dalam bidang filsafat. Konsep filsafat yang mendapat sambutan hangat dari masyarakat Perancis waktu itu adalah paham Eksistensialisme, Fenomenologi, Psikoanalisis, Marxisme dan usaha-usaha untuk menggabungkannya (Hartono, 2007 : 46). Di antara pahampaham ini, yang mendapat minat paling besar adalah kajian Psikoanalisis Lacan yang memandang bahwa persoalan diri atau identitas subjek dan hasrat subjektif, tidak terlepas dari konstruksi sosial melalui permainan bahasa (Strukturalisme).

Dari pengkajian literatur ini maka dapat ditarik kesimpulan bahwa semua akar pemikiran Deleuze dan Guattari bermuara pada peletakan posisi hasrat(Desiring-Machine) agar bisa sejajar dengan rasio.

\section{Teori Deleuze-Guattari}

Teori dalam tulisan ini tidak seluas atau sebanyak teori-teori yang dihasilkan Deleuze dan Guattari selama berkarya, namun secara spesifik terbatas pada interpretasi dari buku Thinkers For Architects dan beberapa referensi penunjang lainnya. Teori yang dibahas di sini adalah teori yang dianggap berpengaruh dalam bidang Arsitektur.

\section{Desiring-Machine}

Hasrat didefinisikan sebagai mesin, mesin hasrat. Jadi hasrat selalu bekerja, tepatnya selalu berproduksi. Aktivitas produksi hasrat bersifat kekal tanpa batasan spasial, temporal, numerik atau kategori apapun (Hartono, 2007 : 117). Esensi hasrat adalah energi kosmis yang selalu memproduksi dalam kosmos. Sebuah proses produksi mencakup tiga hal, yaitu tindakan atau produksi itu sendiri, penyebaran dan konsumsi. Ketiga hal ini tidak dapat dipisahkan karena sebuah proses produksi akan selalu diiringi dengan proses penyebaran dan konsumsi untuk 
selanjutnya berulang lagi menjadi proses reproduksi, penyebaran dan konsumsi kembali, demikian seterusnya. Machine merupakan hal yang benar-benar nyata dan bukan merupakan satu figur semata, ia berada di mana-mana dan saling menghubungkan dirinya, seperti yang dikatakan Deleuze-Guattari (1972 : 1) sebagai berikut:

"It is at work everywhere, functioning smoothly at times, at other times in fits and starts. It breathes, it heats, it eats. It shits and fucks. What a mistake to have ever said the id. Everywhere it is Machines-real ones, not figurative ones: Machines driving other Machines, Machines being driven by other Machines, with all the necessary couplings and connections."

Territorialization-DeterritorializatiionReterritorialization

Territorialization merupakan suatu keadaan di mana totalitas dari seorang manusia dibentuk oleh konvensi bersama dalam kelompok tertentu. Deterritorialization merupakan upaya keluar dari batasan (territory), yaitu suatu keadaan di mana totalitas dari seorang manusia dibentuk oleh konvensi bersama dalam kelompok tertentu yang telah ada sebelumnya. Reterritorialization merupakan sebuah keadaan di mana subjek dibentuk lagi dalam satu tatanan baru setelah melewati proses deterritorialization. Jadi hubungan antara territorializationdeterritorialization-reterritorialization adalah merupakan hubungan yang terus menerus berevolusi didorong oleh hasrat yang selalu ingin mencari suatu keadaan baru. Sebab jika seandainya sebuah proses territorialization menjadi deterritorialization berhenti pada suatu keadaan stagnan, maka sesungguhnya hal itu mengindikasikan bahwa keadaan tersebut masih tetap ada dalam wilayah kemapanan dan konvensi yang jelas-jelas bertentangan dengan konsep Hasrat sebagai penggerak menuju kebaruan yang terus berevolusi.

Proses Territorialization-Deterritorializatiion-Reterritorialization. ini digambarkan dalam perumpamaan kawanan domba (Ballantyne, 2007 : 9). Pada umumnya domba selalu berada dalam kawanan ke manapun mereka pergi dan berada. Suatu ketika ada seekor domba yang bergerak menjauhi kawanannya. Domba ini menjauh bukan karena sakit, lemah ataupun cacat, melainkan karena kekuatannya. Domba tersebut kemudian berjalan mencari suatu keadaan baru untuk hidup. Setelah melakukan pencarian yang cukup panjang dan pada akhirnya menemukan suatu keadaan baru, maka domba tersebut menjadikan keadaan itu sebagai lingkungan baru dengan kawanan yang baru pula dan berusaha hidup di dalamnya. Ini terjadi tidak terbatas hanya satu kali saja, tetapi dapat berkali-kali, sehingga kawasan yang dimiliki domba tersebut akan semakin luas. Menjadi jelas bahwa suatu keadaan di mana domba ini berada pada kawanan yang lama adalah representasi dari konsep Territorialization, sedangkan proses untuk menjauh dari kawanan domba yang lain adalah representasi Deterritorialization, selanjutnya keadaan yang baru dalam komunitas yang baru adalah representasi dari Territorialization. Demikian seterusnya akan terjadi proses evolusi yang sama dengan siklus seperti yang disebutkan di atas. Siklus ini dapat diperjelas dalam Bagan 1 berikut ini : 


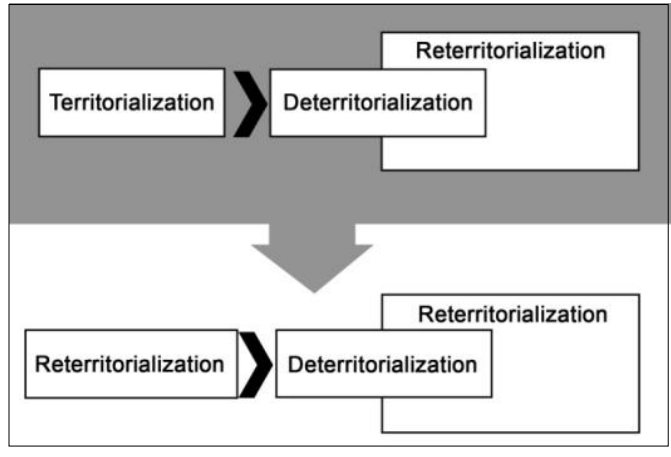

Bagan 1

Proses Territorialization-DeterritorializationReterritotialization

Sumber: Konstruksi Kelompok Penyusun, 2015

\section{Rhizome and Tree}

Menurut Deleuze-Guattari, Rhizome adalah sebuah proses berpikir yang berada di luar kerangka berpikir yang tersentralisasi atau terstruktur. Rhizome sebagai oposisi dari Tree. Tree digambarkan sebagai kekuatan sentral atau model sentralisasi. (Ballantyne, 2007 : 26). Tree adalah simbol hirarki organisatif dalam pemikiran Barat. Pemikiran Barat berasumsi bahwa pikiran atau rasio manusia bisa mengatur segala realitas yang ada di dunia ini. Pemikiran Barat berupaya menata pikiran dengan membentuk prinsip dan konsep tertentu yang bersifat hirarkis dan sistematis/ terstruktur. Prinsip dan konsep ini mewujud dalam bentuk, esensi, hukum, kebenaran, yang bisa dirangkum dalam satu kata yaitu Logos. Jadi logos merupakan fondasi tunggal yang menjabarkan realitas melalui sistem hirarkis dan sistematis. Hal ini dipertegas oleh Deleuze dan Guattari yang menyatakan bahwa pemikiran orang Barat sangat didominasi oleh pola pemikiran yang terpusat/ terstruktur (Deleuze-Guattari, 1980: 18).

Rhizome memungkinkan individu untuk memiliki pandangan dan pemikiran sendiri sehingga dapat tumbuh dan berkembang masingmasing tanpa batas. Ini lagi-lagi terjadi karena adanya dorongan mesin hasrat (Desiring-Machine). Rhizome menolak ide tentang Tree dan sebaliknya memandang segala sesuatu (gagasan, waktu, tempat, manusia dan lain sebagainya) berada dalam situasi saling berhubungan. Rhizome inilah yang mendiami tubuh seorang nomad yang pemikirannya mengembara dan tidak pernah menuntaskan satu pokok permasalahan, tetapi secara sederhana terus bertanya dan berpikir. Keinginan para nomad adalah mencoba hidup tanpa dihalangi peraturan dan kode dominasi (O'Donnell, 2009 : 77). Jadi rhizome merupakan proses pengembaraan cara berfikir seseorang atau dengan kata lain proses berfikir yang tiada akhir sehingga memicu terlahirnya sebuah pemikiran baru.

\section{Pembahasan: Interpretasi Teori Deleuze-Guattari dalam Arsitektur}

Interpretasi Desiring-Machine

Desiring-Machine berperan sebagai proses pembentukan ide dalam diri Arsitek. Sebab Desiring-Machine ini menyangkut segala hal yang bereproduksi baik ide atau apapun. Jadi dalam konteks arsitektur, DesiringMachine berhubungan dengan kreativitas dalam menterjemahkan ide ke dalam bentuk desain perancangan. Biasanya sebelum menghasilkan sebuah desain final seorang arsitek akan memulai dengan berbagai konsep yang meliputi pemilihan struktur bangunan, penggunaan material yang ramah lingkungan, pemilihan warna bangunan maupun pencarian konfigurasi bentuk dan lain sebagainya. Dalam serangkaian proses ini maka sering kali para arsitek akan mengubah 
desain awal menjadi desain yang lebih baru yang dianggap lebih baik dari yang dihasilkan sebelumnya. Di sinilah peran Desiring-Machine begitu menonjol.

Interpretasi

Territorialization-

Deterritorialization-

Reterritorialization

Konsep

Territorialization-

Deterritorialization-

Reterritorialization akan relevan dengan arsitektur dalam hal mencari gagasan-gagasan kebaruan. Konsep ini bisa diamati lewat perkembangan langgam Arsitektur dari waktu ke waktu sepanjang sejarah arsitektur itu sendiri. Misalnya bagaimana zaman Arsitektur Gotik (Gbr. 1) beralih pada Arsitektur Baroque dan Rococo (Gbr. 2) dan selanjutnya Renaissance (Gbr. 3). Kemudian pada perkembangan berikut muncul aliran baru dengan nama Arsitektur Nouveau (Gbr. 4) sampai pada jayanya langgam International Style (Gbr. 5) sebelum dideklarasikan kematiannya lewat penghancuran Pruitt Igoe. Terakhir adalah Arsitektur Postmodernism (Gbr. 6) yang belakangan ini mulai dipertanyakan juga eksistensinya. Semua perubahan langgam dalam sejarah arsitektur ini merupakan refleksi usaha manusia dalam memandang alam beserta lingkungan binaannya untuk mencoba keluar dari nilai, aturan, style yang ada, dengan tujuan menemukan kebaruan sesuai dengan persepsi mereka terhadap situasi yang ideal.

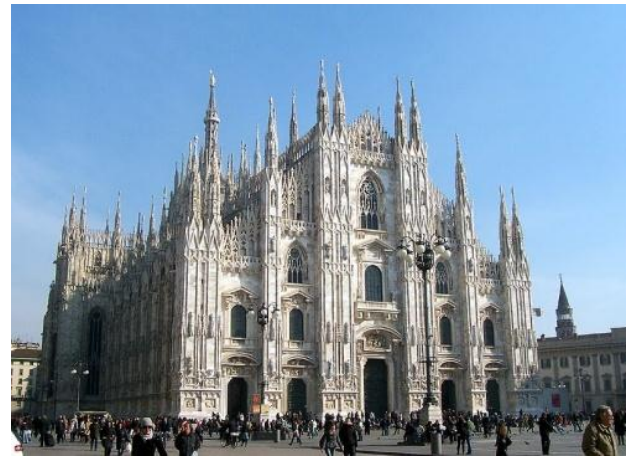

\section{Gambar 1. Arsitektur Gotik}

Sumber:

http://sporttobe.blogspot.com/2010/06/arsitektu r-gothic.html

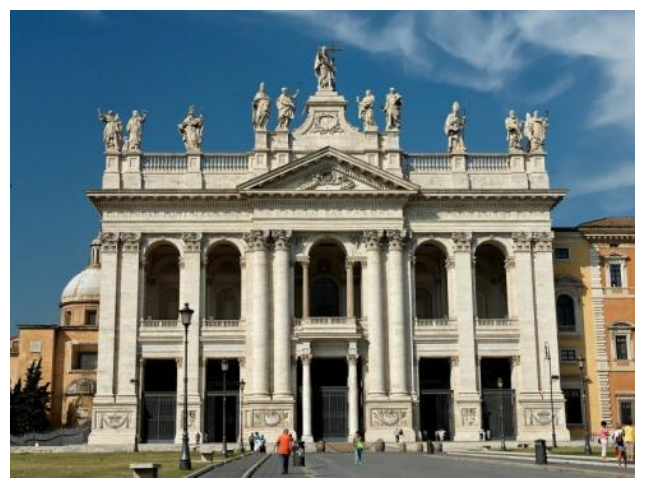

Gambar 2. Arsitektur Baroque dan Rococo Sumber:

http://annasmaulana.blogspot.com/2013/05/seja rah-arsitektur-arsitektur-barok-dan_31.html

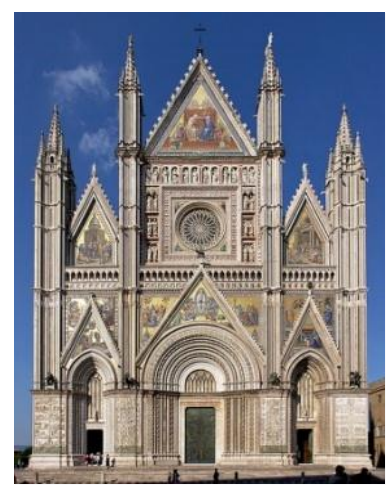

Gambar 3. Arsitektur Renaissance

Sumber:

http://www.popeti.com/berita/artikel/architectu re/ciri-arsitektur-bangunan-itali-di-erarenaisans/ 


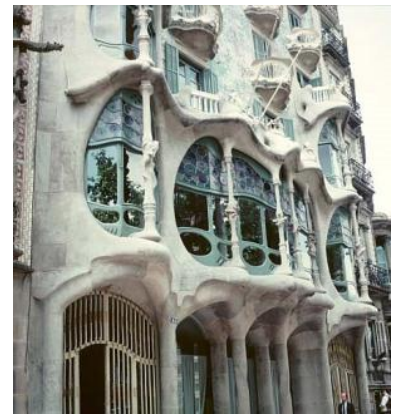

Gambar 4. Arsitektur Art Nouveau

Sumber: http://andywarholisme-

td1a.blogspot.com/2008/03/art-nouveau.html

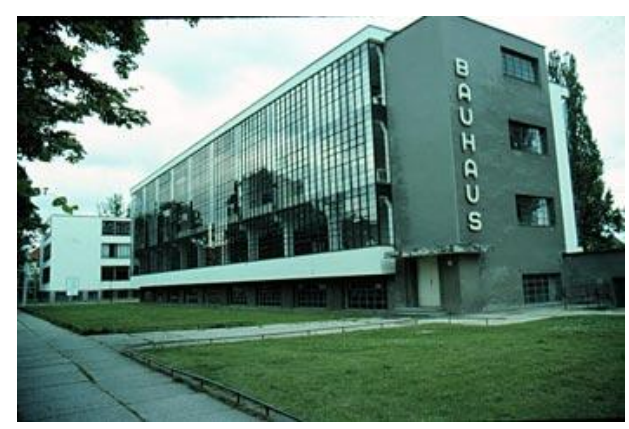

Gambar 5. Arsitektur International Style Sumber:

http://www.solarflarestudios.com/demosites/ar chitecture/international.htm

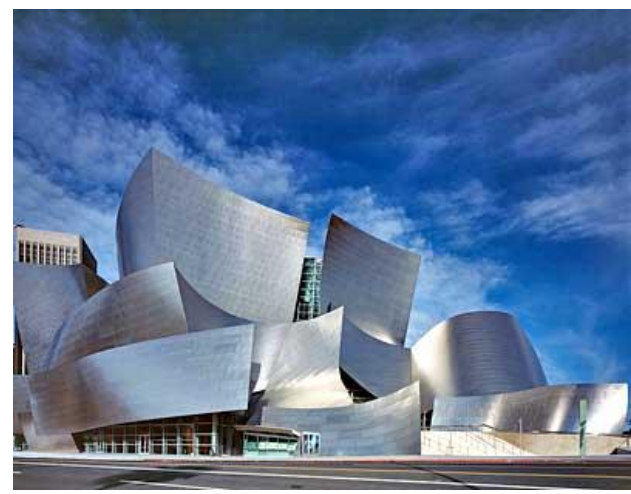

Gambar 6. Arsitektur Postmodernism

Sumber :

http://en.wikipedia.org/wiki/File:Imag-

Disney_Concert_Hall_by_Carol_Highsmith_ed it.jpg

Interpretasi Rhizome

Rhizome dalam arsitektur dapat diartikan sebagai upaya untuk melepaskan diri dari dominasi pemikiran (sebagian) cara berarsitektur bangsa Barat yang cenderung mengabaikan konteks budaya setempat. Perkembangan arsitektur pada beberapa dekade terakhir menunjukkan gejala ini, yaitu dengan munculnya kritik-kritik yang menentang bentukbentuk Arsitektur Postmoderen. Arsitektur Eropa (postmoderen) seakan-akan berdiri dengan gagahnya tanpa memperhatikan konteks sosial dan dampak yang ditimbulkannya baik bagi lingkungan dan masyarakat sekitar. Jadi Rhizome di sini dinyatakan sebagai cara berpikir yang kontekstual, dengan memperlakukan alam dengan sebaik-baiknya dan tentunya mempertimbangkan budaya di mana objek arsitektur itu dihadirkan. Hal ini sangat berbeda dengan produk arsitektur Barat yang cenderung mengabaikan budaya bangsa lain.

Dengan interpretasi yang berbeda rhizome dapat diterjemahkan ke dalam proses pencarian/penemuan bentuk arsitektur yang tidak berupaya mengikuti preseden yang ada. Namun tetap mengeksplorasi image (citra) baru sehingga memunculkan kesan visual yang memikat. Seperti yang dipraktekkan oleh beberapa Starchitects dalam menghasilkan sketsa konfigurasi bentuk. Dapat dilihat di bawah ini sketsa dari Zaha Hadid (Gbr.7), Daniel Libeskind (Gbr.8), Coop Himelblau (Gbr.9), Frank Gehry (Gbr.10), dan Peter Eisenman(Gbr. 11).

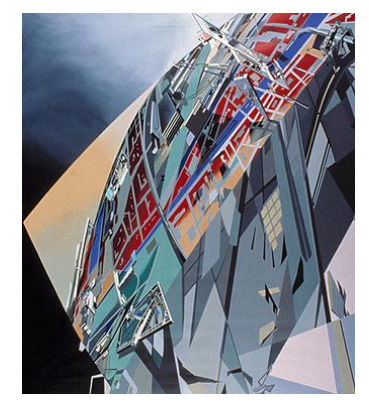

Gambar 7. Sketsa Zaha Hadid

Sumber:

http://www.thecityreview.com/zaha.html 


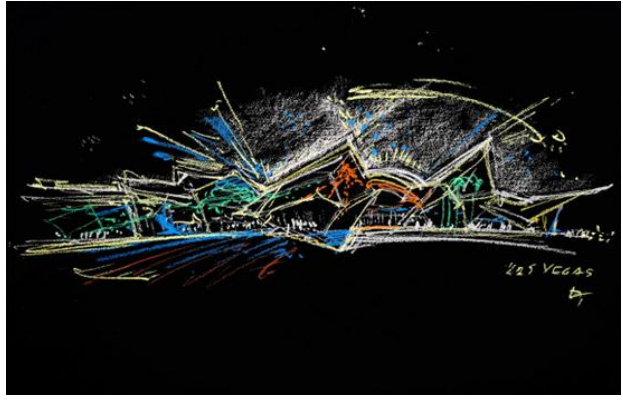

Gambar 8. Sketsa Daniel Libeskind Sumber:

http://www.designboom.com/architecture/danie l-libeskind-mgm-mirage-city-center/

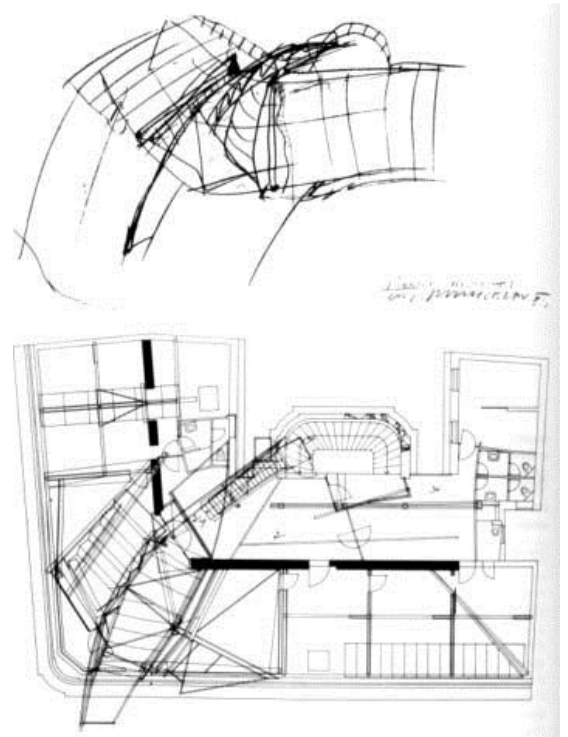

Gambar 9. Sketsa Coop Himelblau

Sumber:

http://histofarch.weebly.com/coophimmelblau. html

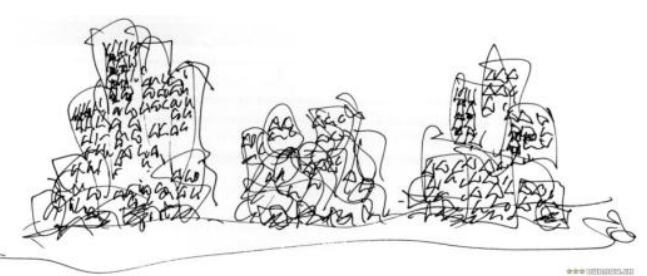

Gambar 10. Sketsa Frank Gehry

Sumber:

http://outnow.ch/Movies/2005/SketchesOfFran kGehry/Bilder/special.xl/03

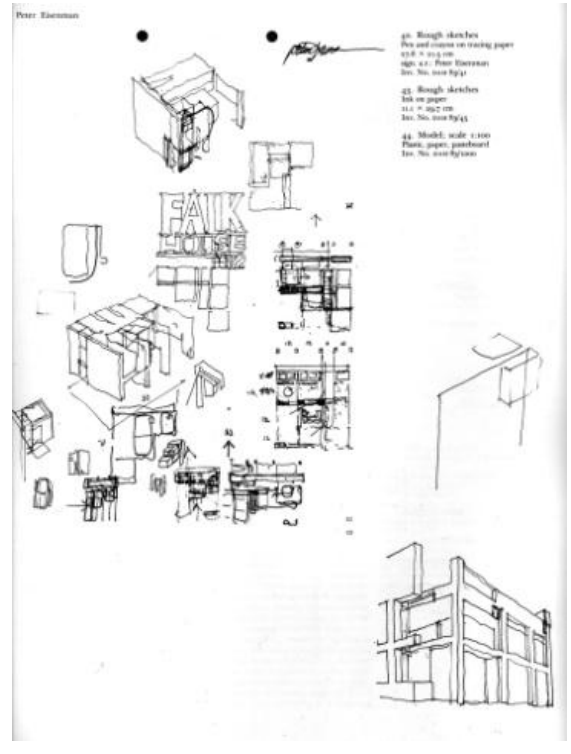

Gambar 11. Sketsa Peter Eisenman

Sumber :

http://www.pinterest.com/pin/22032460674411 4590/

\section{Penutup}

Dari pembahasan di atas dapat ditarik kesimpulan bahwa semua akar pemikiran Deleuze dan Guattari bermuara pada peletakan posisi hasrat agar bisa sejajar dengan rasio. Hasrat merupakan bagian yang tidak terpisah dari cara manusia bereksistensi, terlepas dari rasio yang mendominasi cara manusia bertindak dan berpikir. Hasrat memiliki daya untuk menjadikan manusia lebih kreatif. Hasrat ini pula yang melatar belakangi lahirnya konsep TerritorializationDeterritorialization-

Reterritorialization dan Rhizome.

Dalam Arsitektur, walaupun hanya sebatas pada literatur, konsep DeleuzeGuattari dapat dicari relevansinya melalui proses interpretasi. Namun demikian hal ini tidak menutup kemungkinan untuk bisa dipraktekkan dalam dunia profesi, misalnya konsep Deleuze dan Guattari ini dipakai sebagai alat atau sarana dalam 
menggali kreativitas arsitek untuk mengolah dan menghasilkan bentukan geometris baru, dan yang tidak kalah penting adalah kebaruan konsep bagi penghadiran objek arsitektur itu sendiri. Akhirnya apa yang bisa dicapai dari proses evolusi kebaruan ini ? Tentu, jawabnya ada pada hasrat yang tak pernah terdefinisi dengan pasti.

\section{Daftar Pustaka}

Ballantyne, A. (2007). Thinkers for architects : Deleuze \& Guattari for architects. New York: Routledge.

Deleuze, G. and Guattari, F. (1972). Capitalisme et Schizophrénie 1: L'Anti-Oedipe. Paris: Editions du Minuit ; translated by Robert Hurley, Mark Seem and Helen R. Lane. (1977). Capitalism and Schizophrenia 1 : Anti-Oedipus. New York: Viking.

Deleuze, G. and Guattari, F. (1980). Capitalisme et Schizophrénie 2: Mille Plateaux. Paris: Editions du Minuit; translated Brian Massumi. (1987). Capitalism and Schizophrenia 2: A Thousand Plateaus. Minneapolis: Minnesota University Press.

Hartono, A. (2007). Skizoanalisis Deleuze \& Guattari: Sebuah pengantar genealogi hasrat. Yogyakarta: Jalasutra.

Heidegger, M. (1971). Building dwelling thinking. Dalam Poetry, language, thought (hal. 145-161). New York: Harper \& Row Publisher, Inc.

Mallgrave, H. $\quad$ F., dan Contandriopoulos, C. (2008). Architectural theory. Oxford: Blackwell Publishing

Nesbitt, K. (1996). Theorizing a new agenda for architecture: An anthology of architectural theory. New York: Princeton Architectural Press.

O’Donnell,

$\mathrm{K}$.

(2003).

Postmodernisme. Oxford: Lion publishing; diterjemahkan oleh Jan

Riberu

(2009).

Postmodernisme. Yogyakarta: Kanisius.

Schulz, C. N. (1988). Architecture: meaning and place, selected essays. New York : Rizzoli. 